\title{
Electrochemical Behavior of Fe-Ni Alloys as an Inert Anode for Aluminum Electrolysis
}

Yipeng Huang, Youjian Yang, lingmeng Zhu, Fengguo Liu, Zhaowen Wang*, Bingliang Gao, Zhongning Shi, Xianwei Hu

School of Metallurgy, Northeastern University, Shenyang 110089, China

*E-mail: wangzw@smm.neu.edu.cn

doi: $10.20964 / 2019.07 .42$

Received: 15 September 2018 / Accepted: 9 November 2018 / Published: 10 June 2019

$\mathrm{Fe}-\mathrm{Ni}$ alloys have been regarded as promising candidates for inert anodes of aluminum electrolysis. In this study, a binary $\mathrm{Fe}-\mathrm{Ni}$ alloy with $32 \mathrm{wt} \% \mathrm{Ni}$ content was tested as an inert anode, and its high temperature oxidation and corrosion behavior were studied. Thermogravimetric oxidation showed that the oxidation kinetics followed the parabolic law, and the oxidation rate constant was $9.568 \times 10^{-4} \mathrm{~kg}^{2} \cdot \mathrm{m}^{-}$ ${ }^{4} \cdot \mathrm{h}^{-1}$ at $970{ }^{\circ} \mathrm{C} . \mathrm{Fe}_{2} \mathrm{O}_{3}$ and $\mathrm{Fe}-\mathrm{Ni}-\mathrm{O}$ were identified as two major components of the oxidation scale using a combination of $\mathrm{X}$-ray diffraction and energy dispersive spectrometry. The anodic behavior of preoxidized and non-oxidized $\mathrm{Fe}-\mathrm{Ni}$ alloys in cryolite-alumina melts was studied for the first time in a laboratory-scale transparent electrolysis cell. It was observed that small bubbles were released rapidly on pre-oxidized anodes, while no bubbles were generated on non-oxidized anodes and the molten electrolyte become opaque quickly. These findings confirmed that the precondition of the Fe-Ni alloy is helpful to improve its corrosion resistance.

Keywords: aluminum electrolysis; inert anode; Fe-Ni alloy; corrosion behavior; transparent electrolysis cells

\section{$\underline{\text { FULL TEXT }}$}

(C) 2019 The Authors. Published by ESG (www.electrochemsci.org). This article is an open access article distributed under the terms and conditions of the Creative Commons Attribution license (http://creativecommons.org/licenses/by/4.0/). 